\title{
Clearcutting Brazilian Semiarid Tropics: Observations on Its Effects on Small Ruminant Nutrition during the Dry Season
}

\author{
R.D. KIRMSE, F.D. PROVENZA, AND J.C. MALECHEK
}

\section{Abstract}

Small ruminant production in northeast Brazil is limited by prolonged nutritional stress during the dry season. Our study assessed the effects of clearcutting woody vegetation on the nutrition of goats and sheep during the initial dry season following clearing. Dry matter intake $\left.\left(g \cdot e^{-1 a y}\right)^{-1}\right)$ was higher for animals on cleared than on uncleared areas $(818$ vs. $627 ; P<0.05)$. Extrusa from esophageally fistulated animals grazing cleared, as opposed to uncleared, areas was more digestible ( 52 vs. $47 \% ; P<0.05)$, was similar in crude protein $(7.1$ vs. $7.1 \% ; P>0.05)$, and was lower in neutral detergent fiber ( 49 vs. $51 \% ; P<0.05$ ) and lignin (14 vs. $16 \%$; $P<0.05$ ). Intake and diet quality declined on both cleared and uncleared areas as forage availability declined. Animals on cleared areas benefitted from increased availability of herbs and of biomass from palatable trees that coppiced and retained green leaves throughout much of the dry season. Animals on uncleared areas relied heavily on leaf litter from trees, which provided a poorer quality, but persistent, source of forage throughout the dry season.

Key Words: clearcutting, semiarid tropics, sheep and goats, nutrition, dry season, deferred grazing, coppice, leaf litter

Goat and sheep production in northeast Brazil is often limited by prolonged nutritional stress during the dry season, a time when small ruminants can lose as much as $30-35 \%$ of body weight (Pfister et al. 1983). Clearing woody vegetation is currently promoted as a means of improving livestock production in the Northeast (EMBRATER/EMBRAPA 1980, BNB 1982). Clearing results in a five- to sixfold increase in production of annual herbaceous vegetation, but the proportion of stem increases in relation to leaf and the amount of leaf litter from trees decreases (Araujo Filho et al. 1982, Kirmse et al. 1987a). Many trees coppice following cutting, however, and retain green leaves throughout most of the dry season.

Changes in vegetation structure and composition resulting from clearing may affect goat and sheep nutrition during the dry season. Increasing the proportion of stem to leaf on annual vegetation and decreasing the amount of leaf litter from trees could adversely affect nutrition. Conversely, persistent green foliage on trees that coppice could positively affect nutrition. Our study was designed to assess the effects of clearing on the nutrition of goats and sheep during the dry season. Information on nutritional responses of small ruminants to clearcutting is generally unavailable for the world's rangelands (e.g., Walker et al. 1972, Beale 1973, Van Niekerk et al. 1978, Prachett 1978, Scifres 1980), and few data are available for the semiarid tropics of northeast Brazil (Araujo Filho et al. 1982). Our objectives were to determine the effects of clearing on (1) intake, (2) nutritional quality, and (3) botanical composition of diets of goats and sheep during the dry season.

This is the initial phase of a long-term research program designed to assess the advantages and disadvantages of clearcutting the caatinga as a forest grazing management practice. In this paper we summarize findings related to goat and sheep nutrition

\footnotetext{
Authors are senior agroforester with IRG, $101518 \mathrm{th}$ St. N.W., Suite 802, Washington, D.C. 20036; and with the Range Science Dept., Utah State Univ., Logan 84322.

This research was carried out as part of the United States Agency for International Development Title X1I Small Ruminants Collaborative Research Support Program under Grant No. AID/DSAN/XII-G-0049, in collaboration with Empresa Brasileira de Pesquisa Agropecuarua, Brazil.

Manuscript accepted 13 April 1987
}

on cleared and uncleared caatinga during the initial dry season following cutting. Elsewhere we report on (1) changes in forage production and nutritional quality throughout the year (Kirmse et al. 1987a) and (2) changes in litter production and decomposition (Kirmse et al. 1987b) as a result of clearcutting. Ongoing research is assessing similar parameters for succeeding years. The potential for environmental degradation through repeated clearcutting, the current practice in the caatinga, will also be assessed before making recommendations for national woodland grazing management policy.

\section{Methods}

\section{Study Site}

The study area was near Sobral, Ceara, in northeast Brazil, at $3.5^{\circ}$ south latitude, $41^{\circ}$ west longitude, and $78 \mathrm{~m}$ elevation. Rainfall for 1982 was $705 \mathrm{~mm}$, which was near the 30 -ycar average. The vegetation in the semiarid tropics of northeast Brazil is referred to as caatinga (Eiten and Goodland 1979, Ferri 1980), and is dominated by native deciduous hardwood trees. The study area was divided into 3 blocks of 0.64 ha each and half of each block was cleared before the rainy season of 1982 . The cleared and uncleared blocks, or paddocks, were deferred from grazing until mid-dry season. On 8 October 1982, when vegetation was mature and virtually dormant, 24 indigenous goat and sheep wethers were placed on the 6 treatment paddocks, 2 goats and 2 sheep per paddock. The goats were of mixed breeding and typical of animals commonly found in the local area, and the sheep were of criola ancestry.

This study was designed to span a gradient of declining herbage availability to accentuate potential differences (Gammon 1978) in animal nutrition on cleared and uncleared caatinga (Table 1). The pastures were stocked at a rate of $0.62 \mathrm{AUM} \cdot \mathrm{ha}^{-1}$, which is slightly below the recommended rate (EMBRATER/EMBRAPA 1980) of $0.97 \mathrm{AUM} \cdot \mathrm{ha}^{-1}$ for uncleared caatinga. In general, herbage allowance declined throughout the study, except for late-dry season abscission of leaves from trees that coppiced on clear paddocks.

\section{Intake}

Total fecal collections were used to assess intake on the same 24 animals. We collected feces, from canvas bags attached by harnesses to the animals, every $12 \mathrm{hr}$ for 4 days during each collection period. The feces were dried in a forced-air oven at $105^{\circ} \mathrm{C}$ for $48 \mathrm{hr}$ and weighed. They were subsampled and composited by animal over the 4-day period to determine dry matter and ash. The mean fecal output per day and the mean digestibility of the corresponding esophageal fistula extrusa (see below) were used to calculate dry matter intake (DMI) as follows:

$$
\mathrm{DMI}=\frac{\text { Fecal dry matter qutput } \times 100}{100-\text { Percent in vitro dry matter digestibility }}
$$

\section{Diet Quality}

Eight esophageally fistulated goats and 8 sheep were used to collect samples of diets for nutritional analysis. Between collections fistulated animals were maintained on adjacent cleared and uncleared paddocks. Extrusa samples were collected from the 16 animals, 4 goats and 4 sheep in cleared and 4 goats and 4 sheep in uncleared paddocks, for 3 days ( 1 day per replication) every 2 
Table 1. Herbage allowance and herbage avallable on cleared (C) and uncleared (UC) caatinga at the initiation of four grazing periods during the dry season.

\begin{tabular}{|c|c|c|c|c|c|c|c|c|c|c|c|c|}
\hline \multirow[b]{3}{*}{ Grazing period } & \multirow{2}{*}{\multicolumn{2}{|c|}{$\begin{array}{c}\text { Herbage Allowance } \\
\left(\mathrm{kg} \cdot \mathrm{AU}^{-1}\right) \\
\end{array}$}} & \multirow{2}{*}{\multicolumn{2}{|c|}{$\begin{array}{c}\text { Tree leaf litter } \\
\left(\mathrm{kg} \bullet \mathrm{ha}^{-1}\right)\end{array}$}} & \multicolumn{6}{|c|}{ Herbaceous (kg $\left.\cdot \mathrm{ha}^{-1}\right)$} & \multirow{2}{*}{\multicolumn{2}{|c|}{$\begin{array}{c}\text { Total } \\
\text { herbage }\end{array}$}} \\
\hline & & & & & \multicolumn{2}{|c|}{ Leaf litter } & \multicolumn{2}{|c|}{ Stem } & \multicolumn{2}{|c|}{ Foliage } & & \\
\hline & C & UC & C & UC & $\mathrm{C}$ & UC & C & $\mathrm{UC}$ & $\mathrm{C}$ & $\mathrm{UC}$ & $\mathrm{C}$ & UC \\
\hline Oct. 8-23 & 2,137 & 2,476 & 890 & 2,970 & 230 & 49 & 1,467 & 170 & 177 & 13 & 2,764 & 3,202 \\
\hline Oct. 24-Nov. 8 & 1,368 & 1,994 & 580 & 2,547 & 120 & 18 & 1,050 & 13 & 19 & 0 & 1,769 & 2,578 \\
\hline Nov. $9-23$ & 1,879 & 1,563 & 1,183 & 2,017 & 120 & 4 & 1,127 & 0 & 0 & 0 & 2,430 & 2,021 \\
\hline Nov. 24-Dec. 11 & 1,355 & 1,471 & 676 & 1,899 & 36 & 3 & 1,040 & 0 & 0 & 0 & 1,752 & 1,902 \\
\hline
\end{tabular}

${ }^{1}$ Coppice biomass was measured as leaf litter after abscission (i.e. Nov. 9-23) on cleared areas.

weeks. The early morning collections lasted about $30 \mathrm{~min}$. The sequence of sampling was randomized, but the same group of animals foraged in the same paddock to which they were originally assigned.

Extrusa samples were hand-mixed and composited by species of animal within treatment for each sample period. Samples were air dried at $40^{\circ} \mathrm{C}$ for 3 days, and analyzed for crude protein (AOAC 1975), in vitro dry matter digestibility (Tilley and Terry 1963), neutral detergent fiber, and lignin (Goering and Van Soest 1970). Unlike extrusa samples collected during the wet season, digestibility and fiber analyses of air-dried samples collected from mature forage during the dry season were not affected by Maillard reactions. Pfister and Burritt (1985) found only a $1 \%$ difference in digestibilities between air-dried and freeze-dried samples.

\section{Botanical Composition of Diets}

Extrusa samples were composited by collection period and species of animal, within treatment, and analyzed botanically using a microscope point technique (Harker et al. 1964). Two hundred points were sampled using a binocular microscope set at $15 \times$ magnification. The percent of diet contributed by each plant species and part was calculated as a percent of recognizable species and parts.

\section{Available Forage}

At the beginning of this study on 6 October, and at 2-week intervals corresponding with the extrusa collections, the leaf litter and herbaceous components of the available herbage were sampled. All standing herbaceous vegetation was clipped and all tree and herbaceous leaf litter was collected from 10 quadrats $(50 \times 60 \mathrm{~cm})$ randomly located within each paddock. On the uncleared paddocks this represented total available herbage as all trees had shed leaves. On the cleared paddocks this did not constitute total available herbage because 6 of the trees (Auxemma oncocalyx, Caesalpinia pyramidalis, Combretum leprosum, Mimosa caesalpiniaefolia, Bauhinia forficata, and Caesalpinia ferrea) coppiced and retained green foliage. Coppice standing biomass was sampled indirectly when leaves abcissed in November.

\section{Weight Response}

The 12 goats and 12 sheep were monitored for body weight change. Each animal was weighed at the onset of the experiment on 8 October and at 2-week intervals. Animals were weighed for the last time on 6 December 1982, 2 weeks after the last fecal collection period. By the last weighing the animals had been on the paddocks a total of $2 \mathrm{mo}$. The animals were penned overnight ( $14 \mathrm{hr}$ ) without food or water and weighed between 0600 and $0700 \mathrm{hr}$ the following morning.

\section{Experimental Design}

The statistical design was a factorial with treatment, cleared and uncleared, and animal type, goat and sheep, as the main effects. The experiment was replicated 3 times, and data were collected at 4 periods corresponding to the increasing levels of pasture use. The focus of our study was to compare cleared and uncleared caatinga and not to compare differences between goats and sheep. Where significant $(P<0.05)$ differences exist between goats and sheep, they are discussed in the text. An LSD is presented on figures only when the $\mathrm{F}$ test in the analysis of variance was significant $(P<0.05)$.

\section{Results and Discussion}

\section{Intake}

The amount of forage that sheep and goats consumed declined as weeks of grazing increased (Fig. 1). Clearing significantly $(P<0.05)$ reduced the decline in intake but did not alter the general trend. Others have reported decreases in intake with increasing levels of utilization (Handl and Rittenhouse 1972, Vavra et al. 1973, Malechek et al. 1978). Arnold (1970) suggested that the

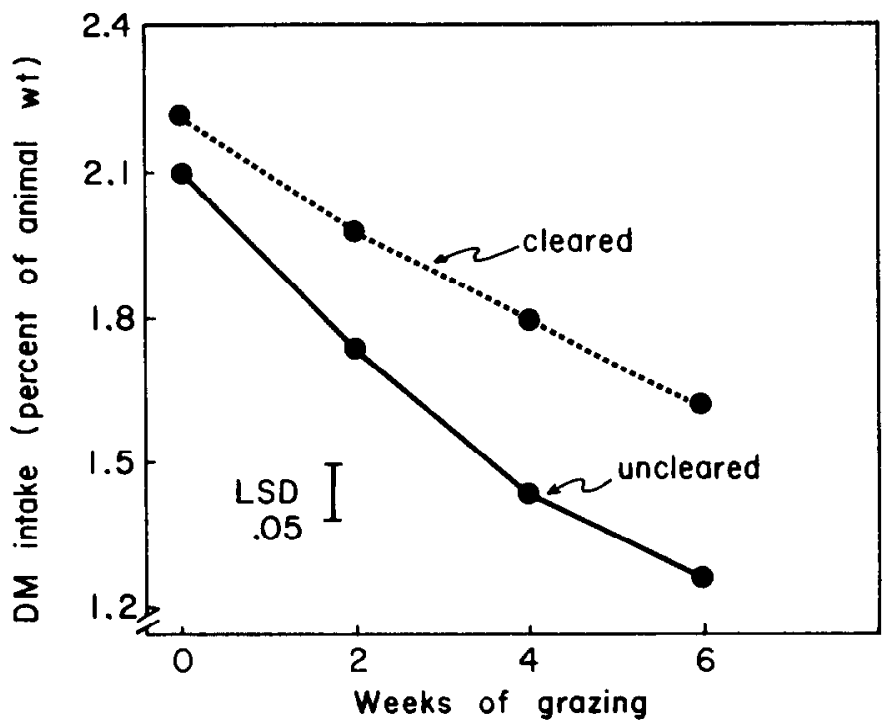

Fig. 1. Dry matter intake of goats and sheep grazing on cleared and uncleared caatinga under increasing levels of pasture use during the dry season, 1982.

decreasing rates of intake associated with declining forage supplies may be caused by animals spending a proportionately greater amount of time searching for favored plant species and parts that are increasingly hard to find. A decline in nutritional quality of forage at higher levels of utilization may also reduce intake as it influences the rate of passage (Van Soest 1982).

\section{Diet Quality}

\section{Digestibility}

Digestibilities decreased as weeks of grazing increased (Fig. 2) possibly because animals were forced to consume plant species and parts that were previously rejected when forage was abundant. As pasture use increased, animals on cleared paddocks maintained diets that were significantly $(P<0.05)$ more digestible than those on the uncleared paddocks. The greater amounts of herbaceous forage and green coppice (see below) probably accounted for the higher digestibilities of diets consumed by animals grazing on cleared paddocks. 


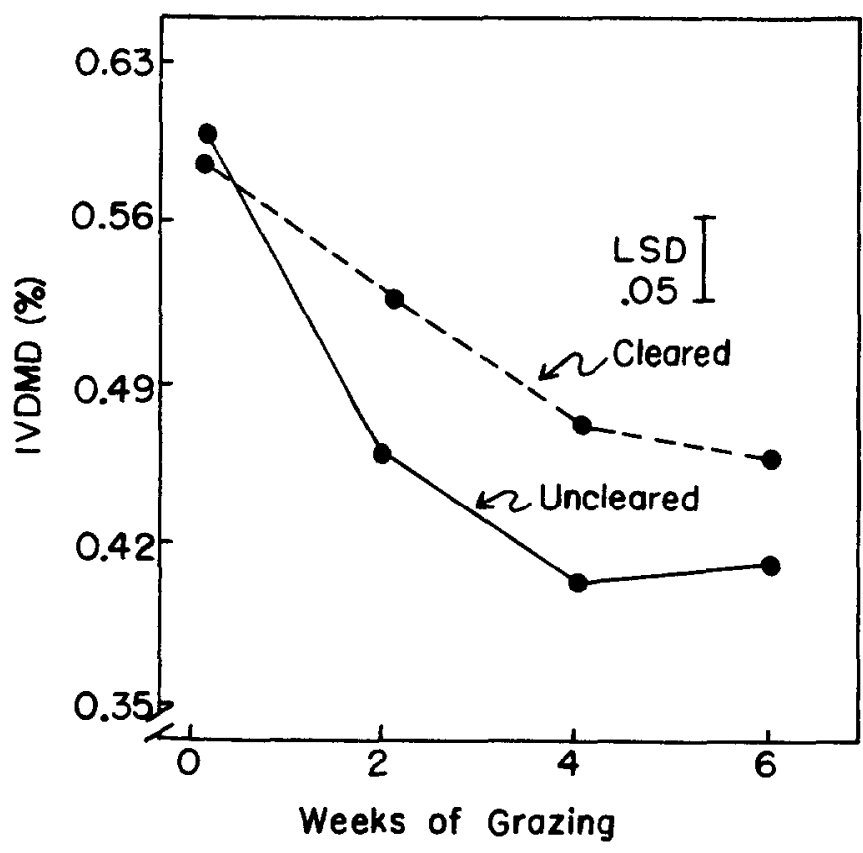

Fig. 2. In vitro dry matter digestibility of the diets of goats and sheep grazing on cleared and uncleared caatinga under increasing levels of pasture using during the dry season, 1982.

\section{Neutral Detergent Fiber and Lignin}

Neutral detergent fiber (NDF) increased after the first 2 weeks of grazing and then stabilized (Fig. 3). There was a general tendency for lower fiber levels in the diets of animals grazing cleared paddocks, and overall this difference was significant $(P<0.05)$. Goats generally had diets higher in NDF $(P<0.05)$ than sheep. The animal species by treatment interaction was also significant $(P<0.05)$ because sheep consumed diets lower in fiber on cleared areas while goats consumed diets similar in fiber on cleared and uncleared areas.

The lignin contents of the diets generally increased as available

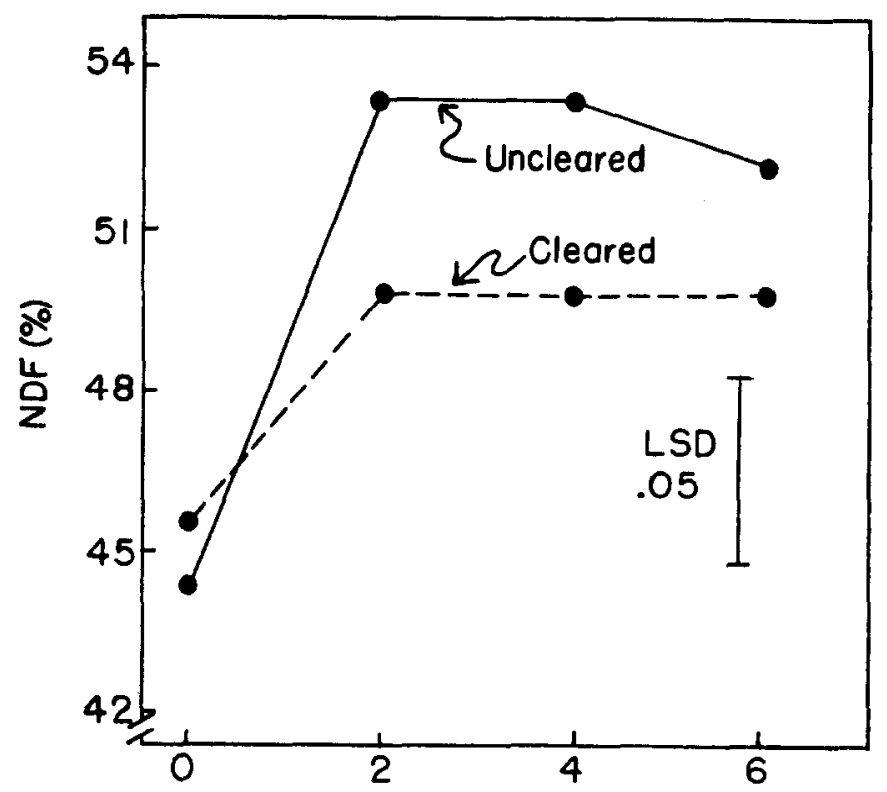

\section{Weeks of Grazing}

Fig. 3. Neutral detergent fiber (NDF) in the diets of goats and sheep grazing on cleared and uncleared caatinga under increasing levels of pasture use during the dry season, 1982. forage decreased, but there was an initial decrease in lignin in diets of animals on cleared paddocks (Fig. 4). The lower lignin levels were possibly related to the reduced amount of tree foliage and increased amounts of herbaceous material at that time (see below).

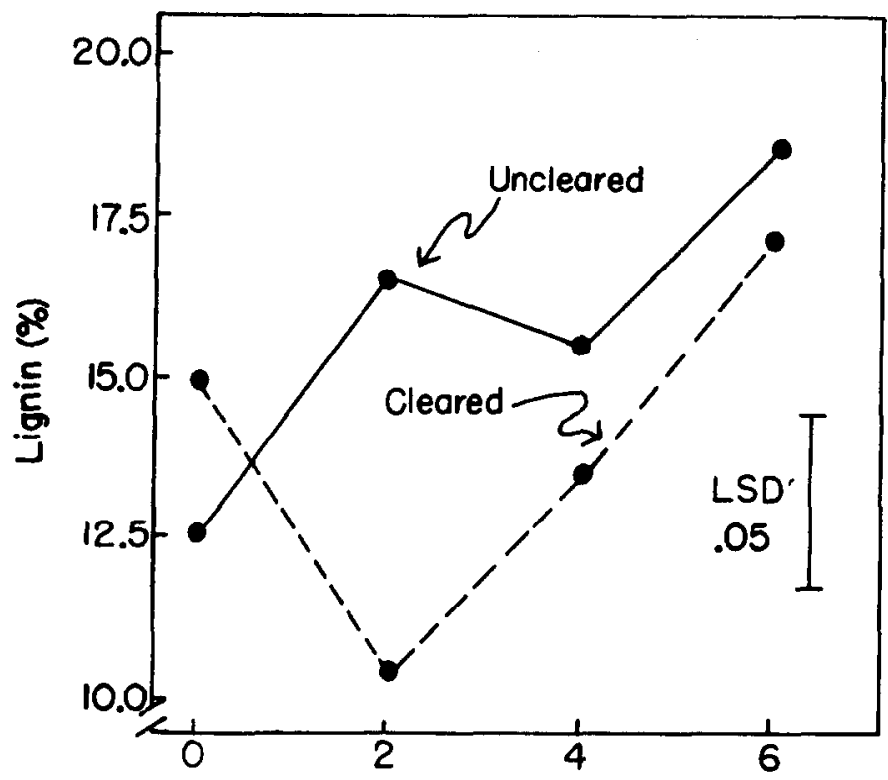

Weeks of Grazing

Fig. 4. Lignin concentrations in the diets of goats and sheep grazing on cleared and uncleared caatinga under increasing levels of pasture use during the dry season, 1982.

The increase in cell wall in diets of goats and sheep grazing on cleared and uncleared paddocks over the first 2 weeks of grazing corresponds with decreasing levels of forage intake. There is evidence that the cell wall fraction of plant tissue is the principal physical fact or controlling rates of digestion and intake (McCammonFeldman 1980, Owen-Smith 1982, Minson 1982). However, dry matter intake continued to decrease with decreasing herbage availability while cell wall content leveled off and the relationship between NDF and intake dropped on cleared $\left(r^{2}=0.59\right)$ and uncleared $\left(r^{2}=0.69\right)$ areas. This apparent anomaly can be explained by the low concentrations of crude protein in the diets at higher levels of pasture use.

\section{Crude Protein}

Levels of crude protein in the diets of sheep and goats tended to be higher on cleared than uncleared paddocks initially, but after 2 weeks of grazing this trend was reversed (Fig. 5). The availability of green foliage from preferred trees that coppiced probably accounted for the initial trend toward higher levels of crude protein in diets of animals on cleared paddocks. We found a similar, although statistically significant, trend in a separate study (Kirmse et al. 1987a). Fiber plays a major role in limiting intake when protein levels are adequate (Minson 1982), but protein levels lower than 6-8\% limit intake (Van Soest 1982). Crude protein levels dropped steadily as weeks of grazing increased, and the pattern of decline was not significantly $(P>0.05)$ influenced by clearing. Apparently, disappearance of forage caused by grazing, in combination with the natural degradation associated with maturity and decomposition, lead to lower crude protein concentrations in the diets.

In contrast to Pfister's (1983) findings, our data suggest that protein may limit utilization of dry season forages by goats and sheep. Differences in yearly rainfall patterns may account for this incongruity. In August, 1981, the year of Pfister's study, a dry season rain stimulated most woody plants to leaf-out. There was no dry season rain during our study in 1982 . These different conclusions may also be caused by differences in project design. In 


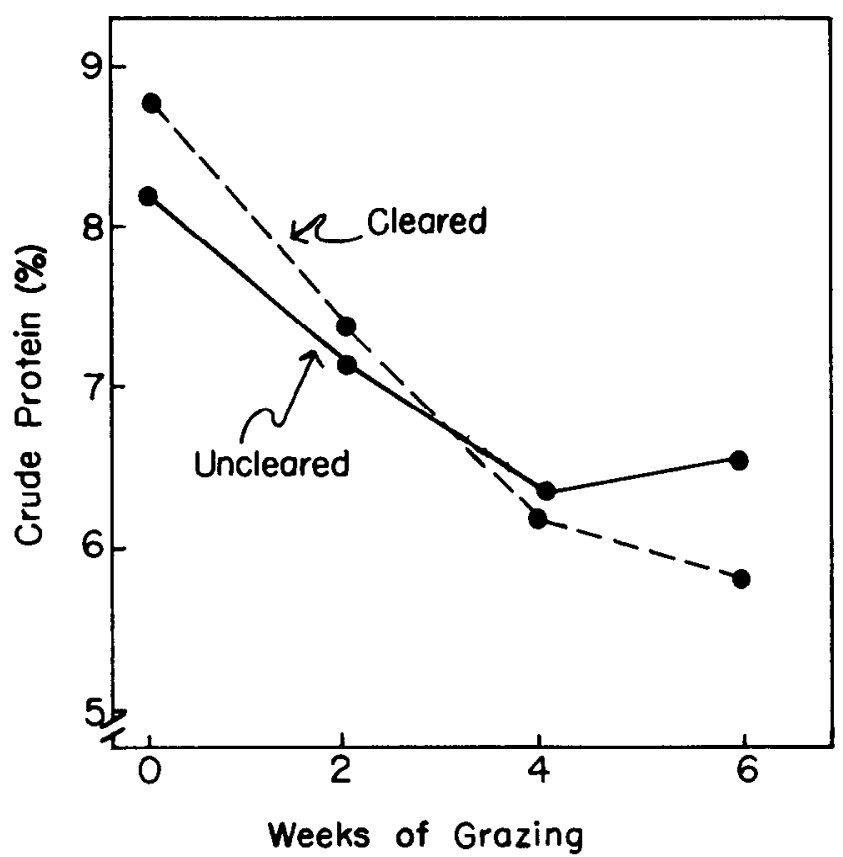

Fig. 5. Crude protein concentrations in the diets of goats and sheep on cleared and uncleared caatinga under increasing levels of pasture use during the dry season, 1982.

our study the animals' ability to select for high protein diets may have been compromised by small, relatively homogeneous paddocks and by heavier levels of use. In contrast, Pfister's study was conducted on a larger, more heterogeneous area that may have allowed the animals a greater opportunity for selective grazing. If protein does limit use of these feeds, more efficient utilization may require supplementation to facilitate rumen function (Morris 1958 and 1966, Van Gylswyk 1970, Minson 1982).

\section{Botanical Composition of Diets}

Sheep and goats increased consumption of leaf litter from tree species on uncleared paddocks after the first 2 weeks of grazing (Fig. 6). Although consumption of leaf litter caused diet quality to decline, tree leaf litter provided an important source of dry season forage. Other researchers have also found tree leaf litter an important source of dry season forage (Hunt 1954, Dougall and Bogden 1958, Wilson et al. 1975, McArthur and Harrington 1978, Pfister 1983).

The major contrast between the 2 treatments was the initial selection for high levels (20\% of diet) of green foliage from trees that coppiced in cleared areas. After 2 weeks of grazing, however, sheep discontinued use of this green forage while goats continued use at a moderate level. Reduced consumption of green foliage from trees that coppiced was probably caused by reduced availability of preferred species. The persistent green foliage used most by goats and sheep was from Mimosa caesalpiniaefolia, Bauhinia forficata, and Caesalpinia ferrea. The remaining green foliage on cleared paddocks was from Auxemma oncocalyx, Caesalpinia pyramidalis, and Cobretum leprosum, species of lower palatability.

The increase in leaf litter in the diets on both cleared and uncleared treatments corresponded with a decline in the amount of herbaceous foliage in the diets and a decreasing abundance of herbaceous vegetation. Herbaceous stem was an important component of the diet throughout the study. Although there was a sixfold increase in production of herbaceous stem on cleared areas, only $28 \%$ of the stems were utilized and there was no significant difference $(P>0.05)$ in the amount of stem consumed on cleared and uncleared caatinga. This is probably because of the corres-

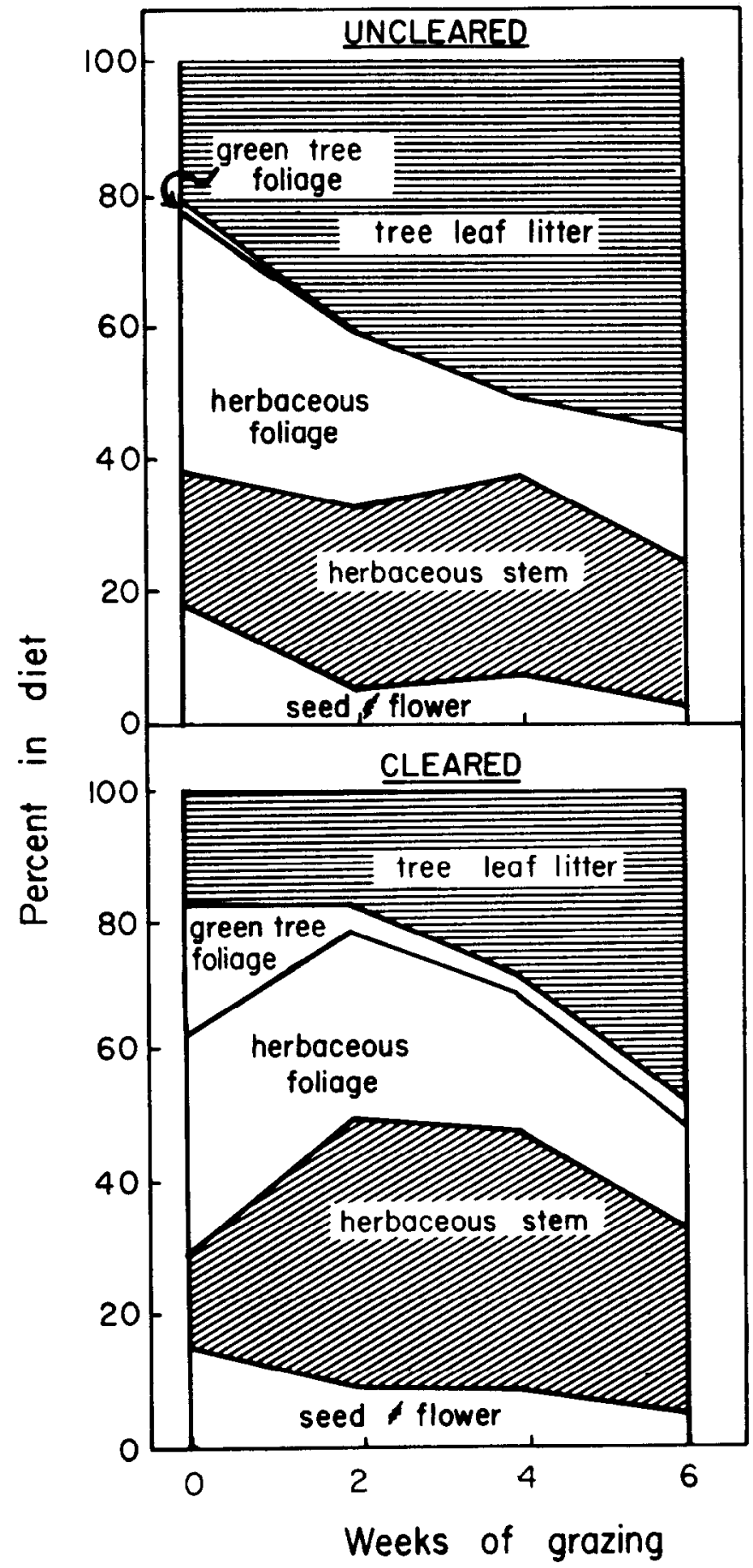

Fig. 6. Plant parts in the diets of goats and sheep grazing on cleared and uncleared caatinga under increasing levels of pasture use during the dry season, 1982.

ponding fivefold increase in diameter of stems on the cleared area compared to those on uncleared areas (Kirmse et al. 1987a). Leaf litter from trees on uncleared areas was the primary forage source, and it gradually declined as it was eaten by goats and sheep. This component of the available biomass increased during the fourth week of grazing on cleared paddocks because trees that coppiced shed their leaves (Table 1).

\section{Weight Response}

Diet quality and intake generally declined as pasture use increased. We attribute this trend to a declining forage supply and 
resultant reduction in the grazing animals' ability to select for forages of higher nutritional quality. Similar results have been observed by researchers in other areas (Blaser et al. 1959, Cook et al. 1965, Vavra et al. 1973, Bryant et al. 1970).

The animals did not, however, exhibit corresponding losses in body weight, nor did improvements in diet quality due to clearing result in significantly higher $(P>0.05)$ weights for animals in cleared areas. The length of the experiment may have been too short to detect weight changes (Petersen and Lucas 1960, Baker 1982), because weight response lags behind changes in diet quality and intake and because changes in diets generally cause a change in gut fill (Corbett 1978). Increased cell wall content, lower levels of crude protein, and lower digestibilities of diets of goats and sheep caused by higher levels of forage utilization should increase retention time of the digesta in the rumen (McCammon-Feldman 1980) and therefore increase rumen fill. An increase in gut fill would, in part, offset possible losses in body weight.

\section{Management Implications}

These results, along with the results of a companion study on leaf litter decomposition (Kirmse et al. 1987b), indicate that leaf litter from trees on uncleared caatinga apparently provides a persistent, albeit poor quality, source of dry season forage. Decisions to clear woody vegetation as a range management practice may, therefore, be a tradeoff between the security of a persistent dry season forage source versus improvements in the quality of the available forage. Ongoing investigations will help elucidate the long-term advantages and disadvantages of clearing caatinga woodland for small ruminant production in northeast Brazil.

\section{Literature Cited}

AOAC. 1975. Official methods of analysis (12th Ed.). Association of Official Analytical Chemists, Washington, D.C.

Araujo Filho, J.A, S.M. Torres, J.A. Gadelha, D.F. Maciel, and A.M. Catunda. 1982. Estudos de pastagem nativa do Ceara. Estudos economicos e sociais 13. Banco do Nordeste do Brasil. Fortaleza.

Arnold, G.W. 1970. Regulation of food intake in grazing ruminants. p. 264-276. In: A.T. Phillipson (ed.) Physiology of Digestion and Metabolism in the Ruminant. Oriel Press, London.

Baker, R.D. 1982. Estimating herbage intake from animal performance. p. 77-94. In: J.D. Leaver (ed.) Herbage Intake Handb. Brit. Grassl. Soc., Hurley, Maidenhead, Berk.

Beale, I.F. 1973. Tree density effects on yields of herbage and tree components in South West Queensland mulga (Acacia aneura F. Muell.) scrub. Tropical Grassl. 7:135-142.

Blaser, R.E., H.T. Bryant, C.Y. Ward, R.C. Hammesk, Jr., R.C. Carter, and N.H. MacLeod. 1959. Symposium on forage evaluation: VII. Animal performance and yields with methods of utilizing pasturage. Agron. J. 51:238-242.

BNB. 1982. Estudos de pastagem nativa do Ceara. Estudos economicos e sociais. Banco do Nordeste do Brazil S.A.

Bryant, T.T., R.E. Blaser, R.L. Hammes, and J.P. Fontenot. 1970. Effect of grazing management on animal and area output. J. Anim. Sci. 30:153.

Cook, C.W., M.M. Kothmann, L.E. Harris. 1965. Effect of range condition and intensity of grazing upon daily intake and nutritional value of sheep on summer range. J. Range Manage. 18:69.

Corbett, J.L. 1978. Measuring animal performance. p. 163-231. In: L. $t^{\text {' }}$ Mannetje (ed.) Measurement of Grassland Vegetation and Animal Production. Bull. 52. Commonwealth Agr. Bur., Farnham Royal, Bucks England.

Dougall, H.W., and A.V. Bogden. 1958. Browse plants of Kenya- with special reference to those occurring in South Baringo. E. Afr. Agr. J. 23:236-245.

Eiten, G., and R. Goodland. 1979. Ecology and management of semi-arid ecosystems in Brazil. p. 277-301. In: B.H. Walker, ed. Management of semi-arid ecosystems. Elsevier, Amsterdam.

EMBRATER/EMBRAPA. 1980. Sistemas de producao para ovinos e caprinos. Sistemas de Producao, Circ. No. 70. Empresa Brasileira de Assistencia Technica e Extensao Rural/Empresa Brasileira de Pesquisa Agropecuaria. Sobral, Ceara.

Ferri, M.G. 1980. Vegetacao Brasileira. Edicaoda Universidade de Sao Paulo.
Gammon, D.M. 1978. A review of experiments comparing systems of grazing management on natural pastures. Proc. Grassl. Soc. So. Afr. 13:75-82.

Goering, H.K., and P.J. Van Soest. 1970. Forage fiber analysis. Agr. Res. Serv. USDA Agr. Handb. No. 379.

Handl, W.P., and L.R. Rittenhouse. 1972. Herbage yield and intake of grazing steers. Proc. West. Sec. Amer. Soc. Anim. Sci. 23:197.

Harker, K.W., D.T. Torell, and G.M. Van Dyne. 1964. Botanical examination of forage from esophageal fistulas in cattle. J. Anim. Sci. 23:465-469.

Hunt, T.E. 1954. The value of browse shrubs and bushes in the lowveld of the Gwanda area, S. Rhodesia, Rhod. Agr. J. 51:251-262.

Kirmse, R.D., F.D. Provenza, and J.C. Malechek. 1987a. Clearcutting Brazilian caatinga: assessment of a traditional forest grazing management practice. Agrofor. Sys. (In Press).

Kirmse, R.D., F.D. Provenza, and J.C. Malechek. 1987b. Effects of clearcutting on litter production and decomposition in semiarid tropics of Brazil. For. Ecol. and Manage: (In Press).

Malechek, J.C., K.J. Kotter, and C.H. Jensen. 1978. Nutrition and production of domestic sheep managed as manipulators of big game habitat. J. Range Manage. 31:92-96.

McArthur, I.D., and G.N. Harrington. 1978. A grazing ecosystem in West Afghanistan. p. 596-599. In: Proc. Ist Internat. Rangeland Congr. Denver, Colo.

McCammon-Feldman, B. 1980. A critical analysis of tropical savanna forage consumption and utilization by goats. PhD. Thesis. Univ. of Illinois at Urbana-Champaign.

Minson, D.J. 1982. Effects of chemical and physical composition of herbage eaten upon intake. p. 167-182. In: J.B. Hacker (ed.) Nutritional Limits to Animal Production from Pastures. Proc. Internat. Symp. Commonwealth Agr. Bur., Farnham Royal. U.K

Morris, J.G. 1958. Drought feeding studies with cattle and sheep. 1. The use of native grass (bush hay) as the basal component of drought fodder for cattle. Queensland J. Agr. Sci. 15:161-180.

Morris, J.G. 1966. Supplementation of ruminants with protein and non protein nitrogen under northern Australian conditions. J. Aus. Inst. Agr. Sci. 32:178-189.

Owen-Smith, N. 1982. Factors influencing the consumption of plant products by large herbivores. p. 359-404. In: B.J. Huntley and B. H. Walker (eds.) Ecology of Tropical Savannas. Springer-Verlag Berling Heidelberg. N.Y.

Petersen, R.G., and H.L. Lucas. 1960. Experimental errors in grazing trials. p. 747-750. In: Proc. 8th Internat. Grassl. Congr. Reading, England.

Pfister, J.A. 1983. Nutrition and feeding behavior of goats and sheep grazing deciduous shrub-woodland in northeastern Brazil. PhD Diss. Utah State Univ. Logan.

Pfister, J.A., J.S. Queiroz, R.D. Kirmse, and J.C. Malechek. 1983. Rangelands and small ruminant production in Ceara, state, Northeast Brazil. Rangelands 5:72-76.

Pfister, J.A., and E.A. Burritt. 1985. Fiber composition of fistulate extrusa samples: Influence of low temperature oven drying. Proc. 38th Annu. Meeting Soc. Range Manage. Salt Lake City, Utah.

Pratchett, D. 1978. Effects of bush clearing on grasslands in Botswana. P. 667-670. In: Proc. Ist Internat. Rangeland Congr. Denver, Colo.

Scifres, C.J. 1980. Brush management. Principles and practices for Texas and the Southwest. Texas A\&M Univ. Press., College Station.

Tilley, J.M.A., and R.A. Terry. 1963. A two-stage technique for the in vitro digestion of forage crops. J. Brit. Grassl. Soc. 18:104-111.

Van Gylswyk, N.O.1970. The effect of supplementing a low-protein hay on the cellulolytic bacteria in the rumen of sheep and on the digestibility of cellulose and hemicellulose. J. Agr. Sci. 74:169-180.

Van Niekerk, J.P., F.V. Bester, and H.P. Lombard. 1978. Control of brush encroachment by aerial herbicide spraying. p. 659-663. In: Proc. Ist Internat. Rangeland Congr., Denver, Colo.

Van Soest, P.J. 1982. Nutritional ecology of the ruminant. O \& B Books Inc., Corvallis, Ore.

Vavra, M., R.W. Rice, and R.E. Bement. 1973. Chemical composition of the diet, intake and gain of yearling cattle on different grazing intensities. J. Anim. Sci. 36:411-414.

Walker, J., R.M. Moore, and J.A. Robertson. 1972. Herbage response to tree and shrub thinning in Eucalyptus populnea shrub woodlands. Aus. J. Agr. Res. 23:405-410.

Wilson, A.D., J.H. Leigh, N.L. Hindley, and W.W. Mulham. 1975. Comparison of the diets of goats and sheep on a Casuarina cristataHeterodendrum oleifolium woodland community in western New South Wales. Aus. J. Exp. Agr. Anim. Husb. 15:45. 